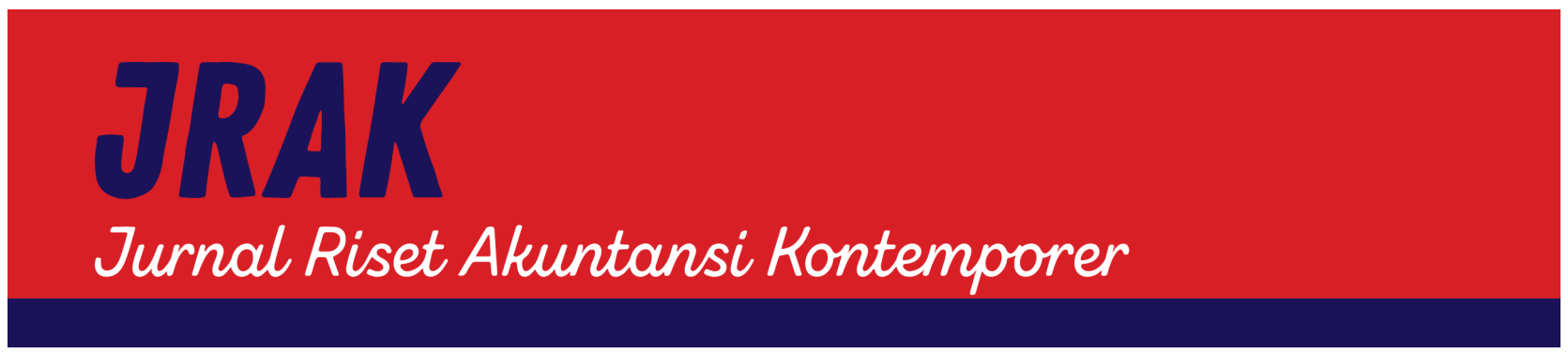

\title{
CRITICAL FACTORS OF CLOUD ACCOUNTING ACCEPTANCE AND SECURITY FOR PROSPECTIVE ACCOUNTANTS: TAM EXTENSION
}

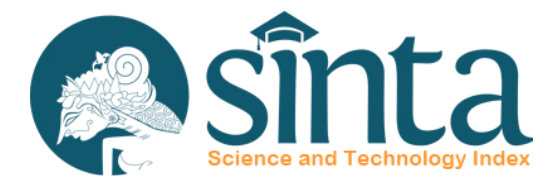

https://journal.unpas.ac.id/index.php/jrak/index

\author{
Ayatulloh Michael Musyafii ${ }^{1} \bowtie$, Arinal Muna² \\ ${ }^{1}$ Universitas Negeri Jakarta \\ ${ }^{2}$ Universitas Swadaya Gunung Jati \\ $\triangle$ musyaffi@unj.ac.id
}

Jl. Rawamangun Muka, RT.10/RW.13, Kec. Pulo Gadung, Kota Jakarta Timur

\section{Article Info}

History of Article

Received: $16 / 10 / 2020$

Revised: 5/3/2021

Published: 25/4/2021

Jurnal Riset Akuntansi Kontemporer

Volume 13, No. 1, April 2021, Page 1-6

ISSN 2088-5091 (Print)

ISSN 2597-6826 (Online)

Keywords: behavior intention; cloud accounting; perceived ease of use; perceived security; technology acceptance model

\begin{abstract}
Cloud computing technology can change the business structure, including accounting, through cloud computing. However, cloud accounting has problems, especially those related to data, which affect user acceptance of cloud accounting. Based on these problems, this research aims to test the acceptance of cloud accounting. The object of this research focuses on cloud accounting users to prospective accountants who are still at the undergraduate degree, with a total of 123 respondents. The questionnaire was distributed via google form and then analyzed using PLS using data processing through SmartPLS. The findings of this study indicate that perceived ease of use and security can influence the intention to using cloud accounting. Meanwhile, perceived usefulness not able to control the choice to use cloud accounting. This is because prospective accountants still consider cloud as a learning medium to not guarantee uncertainty in using cloud accounting.
\end{abstract}

\section{INTRODUCTION}

Cloud computing is the latest technology that can force the business industry to make changes. Cloud computing technology can easily access data and information anywhere and anytime without an internal or external hard drive. According to (Rittinghouse and Ransome, 2017), the functions of cloud accounting include having the speed to access data, reducing maintenance costs, and increasing mobility. These advantages make cloud computing the most critical technology in business and social organizations (Chen, Tian, and Lin, 2018; Cheng, 2018). Cheng (2019) reinforces the argument that currently, cloud computing in the education sector is a recent issue that is currently being discussed. Technology that can support user task suitability will improve user performance (Musyaffi and Muna, 2020). Due to the context of cloud technology, users can easily access data and information anywhere and anytime without the need for specific hardware.

In a survey conducted by Intiut (2019), accounting is a significant area of concern where technology must be applied, namely $29 \%$, followed by marketing at $28 \%$ and human resources at $27 \%$. Besides, a survey conducted by RightScale said that the biggest challenge for cloud technology is the security factor of 29 while Human resources are the second-largest topic at $27 \%$. This is supported by Tarmidi et al. (2014), where the problems that often occur in implementing cloud computing are security issues. 
Based on statistical data, it was found that cloud computing can provide a cost efficiency of $40 \%$ when applied at universities (Kurniawan, 2015). This is shown by using e-learning, which can improve student learning time by $25 \%$ to $50 \%$. (Praveena and Betsy, 2009). In the Sage Practice of Now report, $67 \%$ of professional accountants stated that they are more comfortable using cloud accounting (Thomas-Bryant, 2020). It stands to reason that when using technology, work on accounting can be done easily and quickly. Evidenced by $56 \%$ of accountants agree that accounting technology can increase productivity (Thomas-Bryant, 2019)

Cloud accounting is the latest technology in accounting that can access accounting data and information without requiring physical data such as hard drives. Thus users only need internet access to get the data and information they need. Based on AB Newswire's research, the global cloud accounting market currently predicts an increase of $\$ 4.25$ billion until 2023 (Gilbert, 2020). Companies that use cloud accounting have five times as many customers like companies that do not use cloud accounting (Xero, 2017). This means that the market for developing cloud accounting skills is enormous. This encourages universities, especially prospective accountants, to master cloud accounting from an early age.

The characteristics of a person in adopting technology can be seen from how they accept the technology itself (Musyaffi and Kayati, 2020). According to the Technology Acceptance Model (TAM), a person's acceptance factor is driven by the technology's ease and benefits. (Venkatesh and Bala, 2008; Musyaffi, 2020). Perceived usefulness is the level of perception felt by users in experiencing the benefits and benefits of this technology (Rosnidah et al., 2019). Meanwhile, the perception of ease shows the ease of using technology (Venkatesh, Thong, and Xu, 2012; Gupta, Manrai and Goel, 2019). Technology that users feel is easy and useful will have an impact on the intensity of using this technology (Venkatesh, Thong, and $\mathrm{Xu}, 2012$; Chandio et al., 2013; Motaghian, Hassanzadeh and Moghadam, 2013; Musyaffi, Muna and Fariani, 2016; Rosnidah et al., 2019).

From the perspective of prospective accountants, the existence of cloud accounting can provide easy learning. However, in practice, there is a different acceptance that prospective accountants feel. Users feel that cloud accounting is inefficient mainly because it requires good signal access to generate data and information. A survey conducted by viewpost currently shows that $69 \%$ of Chief Financial Officers (CFO) still excel in making financial reports (Gilbert, 2020). Whereas in the survey The Future of Financial Reporting Survey, technology in the accounting sector has proliferated. One of the factors that encourage accountants' reluctance to use technology is due to security issues $(38 \%)$, higher costs $(35 \%)$, and the complexity of studying the technology (18\%) (Gilbert, 2020).

\section{METHOD}

The population in this research is within the scope of cloud accounting users in accounting information technology courses for accounting students. The sampling method uses a saturated census based on the implementation of cloud accounting as many as 123 accounting students consisting of 6 classes. After using cloud accounting for six months, participants were given an online questionnaire using a google form, then fill out the questionnaire given. After that, the data were analyzed using Partial Least Square (PLS) and processed with SmartPLS 3.0. the use of PLS is used because it can build and test the research model. The stages of using PLS are by testing the outer model, inner model, and model fit test. The final stage is testing the hypothesis (Schumacker and Lomax, 2010; Hair et al., 2014).

The model in this study was measured based on various opinions of researchers. Perceived ease of use and behavioral intention variables are measured through 4 indicators (Venkatesh and Bala, 2008; Musyaffi and Kayati, 2020). Simultaneously, the perceived usefulness variable is measured through 4 indicators (Brown et al., 2003; Luarn and Lin, 2005; Sripalawat, Thongmak and Ngramyarn, 2011). For more details, the measurements in this research eye are described in Table 1.

\section{RESULT}

The results of this research include data analysis and comprehensive discussion. After examining further step by step in the PLS analysis, data analysis is obtained, namely analyzing the inner model, outer model, and hypothesis testing. The outer model test was performed, and the outer loading value provided by SmartPLS was compared to the recommended limit of 0.6. (Hair et al., 2014). Based on Figure 1, the outer loading value for all indicators exceeds the recommended value, which is 0.6 , which means that this research is acceptable. 
Table 1. Measurement

\begin{tabular}{lcll}
\hline Variable & No & \multicolumn{1}{c}{ Measurement } & \multicolumn{1}{c}{ Source } \\
\hline Perceived security & 1 & Implement security measures & Koufaris \& Hampton-Sosa (2004) \\
& 2 & The ability to verify users' identity & Zhou (2011) Cheung \& Lee (2001) \\
Perceived usefulness & 3 & Ensure the security of payment information & \\
& 1 & Give more advantage & Sripalawat et al., (2011) (Brown, Cajee, Davies, \\
& 2 & Finish immediately & \& Stroebel, 2003; Luarn \& Lin, 2005) \\
& 3 & Convenient to use & \\
Perceived ease of use & 4 & Useful & Clear and understandable \\
& 2 & Less effort & (2020), (Singh \& Srivastava, 2018) \\
& 3 & Easy to use & \\
Behavioural Intention & 4 & Easy to get & \\
& 1 & Intend to use & \\
& 2 & Try to use & \\
& 3 & Frequently to use & \\
4 & Recommend to the others & \\
\hline
\end{tabular}

Then to measure the validity of the data, Cronbach Alpha (CA) and Average Variance Extracted (AVE) tests were carried out with the recommended value of each value exceeding 0.7 for CA and 0.5 for AVE (Hair et al., 2014). When the CA and AVE values are above 0.7 , the item is declared valid. Meanwhile, to determine the reliability of the data, it was analyzed using Composite Reliability (CR) with a recommended value of at least 0.7 (Hair et al., 2014). Table 2 shows the results of the CA, AVE, and CR values. Based on Table 2, the $\mathrm{CA}$ and AVE values exceed the recommended values, namely 0.7 and 0.5 . Thus, all variables in this study have valid data. Simultaneously, the smallest CR value is in table 2 of 0.821 in the Perceived Security variable. Thus the variables in the study have reliable data.

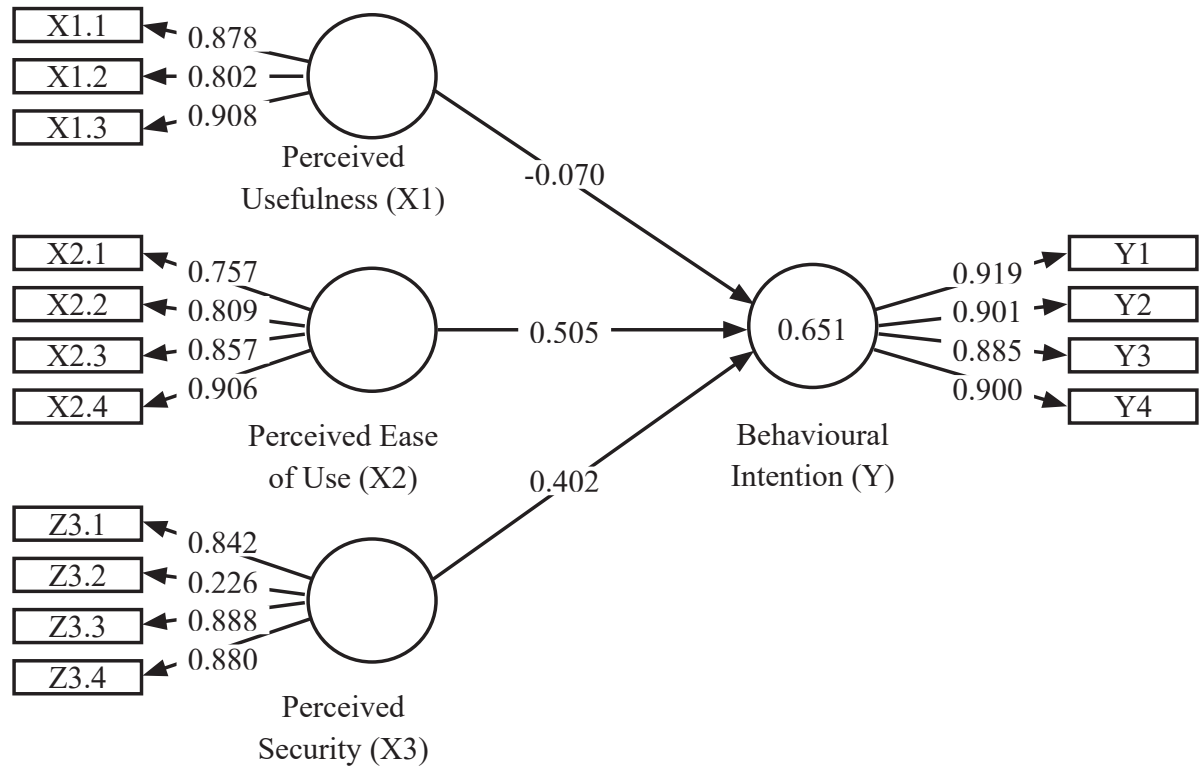

Figure 1. Outer Loading

Table 2. Validity and Reliability

\begin{tabular}{cccc}
\hline & AVE & CA & CR \\
\hline BI (Y) & 0.812 & 0.923 & 0.945 \\
PEOU (X2) & 0.696 & 0.853 & 0.901 \\
PS (X3) & 0.581 & 0.706 & 0.827 \\
PU (X1) & 0.746 & 0.829 & 0.898 \\
\hline
\end{tabular}


Then, to determine the combined effect on the y variable, $r$ square analysis was carried out. Based on Table 3 , the R square value is $65.1 \%$. This means that perceived usefulness, perceived ease of use and perceived security have an effect of $65.1 \%$ on behavioral intention.

Table 3. R Square and R Square Adjusted

\begin{tabular}{ccc}
\hline & R Square & R Square Adjusted \\
\hline $\mathrm{BI}(\mathrm{Z})$ & 0.651 & 0.643 \\
\hline
\end{tabular}

Hypothesis testing is analyzed by comparing the specified error value $(5 \%)$ with the $p$-value. If the $p$-value is less than the error level, the hypothesis proposed by the researcher is accepted (Hair et al., 2014). Based on Table 4, perceived ease of use and perceived security have significant effect on behavioral intention, meanwhile perceived usefulness has little impact on behavioral intention.

Table 4. Hypothesis Testing

\begin{tabular}{ccccc}
\hline & Original Sample $(\mathrm{O})$ & T Statistics $(\mathrm{O} / \mathrm{STDEV})$ & P-values & Decision \\
\hline PEOU $(\mathrm{X} 2) \rightarrow$ BI (Y) & 0.505 & 6.004 & 0.000 & Accepted \\
PS (X3) $\rightarrow$ BI (Y) & 0.402 & 4.456 & 0.000 & Accepted \\
PU (X1) $\rightarrow$ BI (Y) & -0.070 & 1.102 & 0.271 & Rejected \\
\hline
\end{tabular}

\section{DISCUSSION}

Cloud accounting has proven to be an excellent learning tool for users (aspiring accountants). The existence of cloud accounting provides convenience and security for users to learn accounting science comprehensively. This is evidenced in the results of this survey, where convenience is the most influential element on the intention of prospective accountants to adopt cloud accounting. The high level of closeness of the relationship is 50.5\%, making users better understand learning in accounting. The results of this study are also confirmed by previous studies, which show that perceived ease of use is an essential factor in convincing consumers to use cloud accounting (Venkatesh and Bala, 2008; Alalwan et al., 2016; Ben Mansour, 2016). The younger the technology used, the greater the likelihood of adopting the technology (Musyaffi and Kayati, 2020).

In the TAM model, it is said that the variables that influence a person's behavior are the perception of usefulness and convenience. In this research, security becomes an amplifier in perfecting the TAM model, especially in using cloud accounting. Security is an essential factor in someone's consideration to adopt a technology. Researchers agree that security is an essential factor influencing a person's intention to adopt technology (Giovanis, Binioris and Polychronopoulos, 2012; Fonchamnyo, 2013; Leong, Ping, and Muthuveloo, 2017; Ameen et al., 2020). Perceived security is the most important feature of other studies, often supported by other scholars (Kim and Forsythe, 2010; Shah, Peikari and Yasin, 2014; Patel and Patel, 2017, 2018). From the research results by researchers and other research researchers, it can be concluded that security is the main focus of cloud accounting users on prospective accountants. This is because there will be the possibility of data being leaked and misused. So, the importance of infrastructure and commitment from cloud accounting service providers to provide data security guarantees.

The findings of this study also provide some concrete evidence that perceived usefulness does not significantly impact prospective accountants' intention to adopt cloud accounting. The same result was noticed by Chao (2019) about mobile learning adoption, where students are conscious of the utility of mobile learning. However, not necessarily the technology is used continuously. Likewise, in the context of this research, especially on the use of cloud accounting for prospective accountants. The users agree that cloud accounting can provide significant benefits, especially in terms of data processing speed. Data in the field also shows that perceived usefulness has the most significant average value compared to convenience and privacy. Currently, for prospective accountants, cloud accounting is seen as a medium of learning only. Other courses do not necessarily use cloud accounting as their learning media, which causes uncertainty in using cloud accounting.

\section{CONCLUSION}

This study aims to identify the factors that influence the adoption of cloud accounting among prospective accountants who are currently in college. The research model refers to the Technology Acceptance Model (TAM) and perceived security theory, which are the main problems in adopting cloud accounting. Furthermore, 
the findings of this study show that perceived ease of use is the most influential element in consumer behavior when it comes to cloud accounting adoption. The ease of access and use of cloud accounting is the most crucial aspect in its adoption. Meanwhile, the perception of security is a big enough variable to support users' interest in adopting cloud accounting. This is because there will be the possibility of data being leaked and misused. So, the importance of infrastructure and commitment from cloud accounting service providers to provide data security guarantees. However, perceived usability does not have a significant impact on cloud usage behavior. This is because the prospective accountants still view cloud accounting as a medium of learning only. Other courses do not necessarily use cloud accounting as a learning medium, causing uncertainty in using cloud accounting for the learning needs of these students.

\section{REFERENCES}

Alalwan, A. A., Dwivedi, Y. K., Rana, N. P., \& Williams, M. D. 2016. Consumer Adoption of Mobile Banking in Jordan: Examining the Role of Usefulness, Ease of Use, Perceived Risk and Self-Efficacy. Journal of Enterprise Information Management..

Ameen, N., Tarhini, A., Shah, M. H., \& Madichie, N. O. 2020. Employees'Behavioural Intention to Smartphone Security: A Gender-Based, Cross-National Study. Computers in Human Behavior, 104, 106184.

Brown, I., Cajee, Z., Davies, D., \& Stroebel, S. 2003. Cell Phone Banking: Predictors of Adoption in South Africa - an Exploratory Study. International Journal of Information Management, 23(5), 381-394.

Hussain Chandio, F., Irani, Z., Abbasi, M. S., \& Nizamani, H. A. 2013. Acceptance of Online Banking Information Systems: an Empirical Case in a Developing Economy. Behaviour \& Information Technology, 32(7), 668-680.

Chao, C.-M. 2019. Factors Determining the Behavioral Intention to Use Mobile Learning: An Application and Extension of the UTAUT Model, Frontiers in psychology, 10, p. 1652.

Chen, Z., Tian, L. and Lin, C. 2018. Trust Evaluation Model of Cloud User Based on Behavior Data, International Journal of Distributed Sensor Networks, 14(5), pp. 1-10.

Cheng, Y.-M. 2018. What Drives Cloud ERP Continuance? An integrated View, Journal of Enterprise Information Management, 31(5), pp. 724-750.

Cheng, Y.-M. 2019. How Does Task-technology Fit Influence Cloud-Based e-learning Continuance and Impact?, Education+ Training, 61(4), pp. 480-499.

Fonchamnyo, D. C. 2013. Customers' Perception of E-banking Adoption in Cameroon: An Empirical Assessment of an Extended TAM, International Journal of Economics and Finance, 5(1), pp. 166-176. Available at: https://financesonline.com/accounting-statistics-analysis-of-trends-data-and-marketshare/\#cloud.

Gilbert, N. 2020. 82 Essential Online Accounting Statistics: 2020 Data and Market Share Analysis.

Giovanis, A.N., Binioris, S. and Polychronopoulos, G. 2012. An Extension of TAM Model with IDT and Security/Privacy Risk in the Adoption of Internet Banking Services in Greece, EuroMed Journal of Business, Vol. 7 No. 1, pp. 24-53. https://doi.org/10.1108/14502191211225365

Gupta, K. P., Manrai, R. and Goel, U. 2019. Factors Influencing Adoption of Payments Banks by Indian Customers: Extending UTAUT with Perceived Credibility, Journal of Asia Business Studies, 13(2), pp. 173-195.

Hair Jr, J. F., Sarstedt, M., Hopkins, L., \& Kuppelwieser, V. G. 2014. Partial Least Squares Structural Equation Modeling (PLS-SEM): An Emerging Tool in Business Research. European business review.

Kim, J. and Forsythe, S. 2010. Factors Affecting Adoption of Product Virtualization Technology for Online Consumer Electronics Shopping, International Journal of Retail \& Distribution Management.

Koufaris, M., \& Hampton-Sosa, W. 2004. The Development of Initial Trust in an Online Company by New Customers. Information \& management, 41(3), 377-397.

Kurniawan, E. 2015. Penerapan Teknologi Cloud Computing Di Universitas Studi Kasus: Fakultas Teknologi Informasi UKDW. Jurnal Eksplorasi Karya Sistem Informasi dan Sains, 8(1).

Leong, G. W., Ping, T. A. and Muthuveloo, R. 2017. Antecedents of Behavioural Intention to Adopt Internet of Things in the Context of Smart City in Malaysia, Global Business \& Management Research, 9.

Luarn, P. and Lin, H. 2005. Toward an Understanding of the Behavioral Intention to Use Mobile Banking, Computers in Human Behavior, 21(6), pp. 873-891. doi: 10.1016/j.chb.2004.03.003.

Mansour, K. 2016. An Analysis of Business' Acceptance of Internet Banking: an Integration of e-Trust to the TAM. Journal of Business \& Industrial Marketing, 31(8), pp. 982-994. doi: 10.1108/JBIM-10-2016-271.

Motaghian, H., Hassanzadeh, A. and Moghadam, D. K. 2013. Factors Affecting University Instructors' Adoption of Web-based Learning Systems: Case Study of Iran, Computers \& Education, 61, pp. 158-167. 
Musyaffi, A. M. 2020. Perspektif Kritis Kesuksesan Implementasi Cloud Accounting Bagi Calon Akuntan: Kajian Model UTAUT \& IS Succes Model', Substansi: Sumber Artikel Akuntansi Auditing dan Keuangan Vokasi, 4(1), pp. 17-38.

Musyaffi, A. M. and Kayati. 2020. Dampak Kemudahan dan Risiko Sistem Pembayaran QR Code: Technology Acceptance Model (TAM) Extension, Jurnal Inspirasi Bisnis dan Manajemen, 3(2), pp. 161-176.

Musyaffi, A. M. and Muna, A. 2020. Task Technology-Fit of a Village Financial System (Siskeudes) to Increase Officers' Performance, in KnE Social Sciences, pp. 720-730.

Musyaffi, A. M., Muna, A. and Fariani, N. 2016. Pengaruh Persepsi Kemudahan dan Persepsi Kegunaan terhadap Penerimaan Pengguna Sistem Informasi Akademik Terpadu. JRAK: Jurnal Riset Akuntansi dan Komputerisasi Akuntansi, 7(2), pp. 71-82.

Patel, K. J. and Patel, H. J. 2017. Adoption of Internet Banking Services in Gujarat: an Extension of TAM with Perceived Security and Social Influence, International Journal of Bank Marketing, 36(1), pp. 147169. doi: https://doi.org/10.1108/IJBM-08-2016-0104.

Patel, K. J. and Patel, H. J. 2018. Adoption of Internet Banking Services in Gujarat, International Journal of Bank Marketing.

Praveena, K. and Betsy, T. 2009. Application of Cloud Computing in Academia, IUP Journal of Systems Management, 7(3), pp. 50-54.

Rittinghouse, J. W. and Ransome, J. F. 2017. Cloud Computing: Implementation, Management, and Security. CRC press.

Rosnidah, I., Muna, A., Musyaffi, A. M., \& Siregar, N. F. 2019. Critical Factor of Mobile Payment Acceptance in Millenial Generation: Study on the UTAUT Model. In International Symposium on Social Sciences, Education, and Humanities (ISSEH 2018) (pp. 123-127). Atlantis Press.

Schumacker, R. E. and Lomax, R. G. 2010. A Beginner's Guide to Structural Equation Modeling. psychology press.

Shah, M. H., Peikari, H. R. and Yasin, N. M. 2014. The Determinants of Individuals' Perceived e-Security: Evidence from Malaysia, International Journal of Information Management, 34(1), pp. 48-57.

Sripalawat, J., Thongmak, M. and Ngramyarn, A. 2011. M-Banking in Metropolitan Bangkok and a Comparison with other Countries, Journal of Computer Information Systems, 51(3), pp. 67-76. doi: 10.1080/08874417.2011.11645487.

Tarmidi, M., Rasid, S. Z. A., Alrazi, B., \& Roni, R. A. 2014. Cloud Computing Awareness and Adoption Among Accounting Practitioners in Malaysia. Procedia-Social and Behavioral Sciences, 164, 569-574.

Thomas-Bryant, K. 2019. The Practice of Now 2019: An Essential Report for Accountants. Available at: https://www.sage.com/en-gb/blog/practice-of-now/.

Thomas-Bryant, K. 2020. 6 Ways to Make Managing Financial Data Easier for Your Business. Available at: https://www.sage.com/en-gb/blog/managing-financial-data-easier/.

Venkatesh, V. and Bala, H. 2008. Technology Acceptance Model 3 and a Research Agenda on Interventions, Decision Sciences, 39(2), pp. 273-315. doi: 10.1111/j.1540-5915.2008.00192.x.

Venkatesh, V., Thong, J. Y. L. and Xu, X. 2012. Consumer Acceptance and Use of Information Technology : Extending the Unified Theory, MIS Quarterly, 36(1), pp. 157-178. doi: 10.1017/CBO9781107415324.004.

Xero. 2017. Cloud-based Accounting Firms Add Five Times the Amount of Clients of Traditional Firms. Available at: https://www.xero.com/blog/2017/05/cloud-based-accounting-firms-add-five-times-theamount-of-clients-of-traditional-firms/.

Zhou, T. 2011. An Empirical Examination of Initial Trust in Mobile Banking, Internet Research, Vol. 21 No. 5, pp. 527-540. 